MARIUSZ DEMBIŃSKI

Uniwersytet im. Adama Mickiewicza

w Poznaniu

\title{
EDUKACJA JAKO NOŚNIK DOŚWIADCZENIA PEDAGOGICZNEGO \\ W KONTEKŚCIE KREACJI PODMIOTU PEDAGOGICZNEGO. PRÓBA USTANOWIENIA POSTPEDAGOGIKI ${ }^{1}$
}

\begin{abstract}
Aвstract. Dembiński Mariusz, Edukacja jako nośnik doświadczenia pedagogicznego w kontekście kreacji podmiotu pedagogicznego. Próba ustanowienia postpedagogiki [Education as a Vehicle of Pedagogical Experience in the Context of Creating a Pedagogical Subject. An Attempt to Establish Post-Pedagogy]. Studia Edukacyjne nr 45, 2017, Poznań 2017, pp. 77-93. Adam Mickiewicz University Press. ISSN 12336688. DOI: $10.14746 /$ se.2017.45.7

In this article, I want to propose post-pedagogy - a knowledge which is independent of social science. For this purpose, I use the content of pedagogy to create a sense of pedagogical experience and to define the model of the pedagogical subject. Creation should be carried out using the principles of thinking and pedagogical activities, transforming information about the education system in educational activities, which comprise upbringing and training.
\end{abstract}

Key words: post-pedagogy, pedagogical subject, pedagogical experience, principles of thinking and pedagogical activities

Gdyby komuś niebacznie udało się stworzyć uniwersalna definicję wychowania to pojawiłaby się możliwość zunifikowania wszystkich umystów. Jednak, i to na szczęście, rzeczywistym sensem nauk o wychowaniu jest tylko unifikująca możliwość oglądu siebie i wgladu w innych.

\section{Wprowadzenie}

Jeżeli wprowadza się motto przed tekst, to nie po to, aby stanowiło ono jego ozdobnik, ale by dało do myślenia i wyznaczało dodatkowy, ukryty, ale ważny wymiar temu, co w swoim znaczeniu wydaje się już oznaczone.

${ }^{1}$ Artykuł dedykuję prof. dr. hab. Bogusławowi Śliwerskiemu z okazji otrzymania tytułu Doktora Honoris Causa za „Zasługi dla rozwoju polskiej pedagogiki”, Bydgoszcz 5.12.2016 roku. 
A co jest oznaczone? Gdybym miał w jednym zdaniu streścić całość prowadzonych tutaj dywagacji, napisałbym: Prowadzone rozważania stanowią próbę opisania istoczenia się pedagogicznego podmiotu na podstawie doświadczenia pedagogicznego, tworzonego przez zasady myślenia i działania pedagogicznego, stając się siłą motywacyjną, przetwarzającą informacje systemu edukacyjnego w edukacyjne działanie, które jako nośnik wychowania i kształcenia umożliwia jaźni wejście z nimi w relacje, a sposób kreacji tej relacji okazuje się źródłem istnienia podmiotu pedagogicznego i jego mocy sprawczej.

Na ile powyższe zdanie jest zrozumiałe i dlaczego jest niezrozumiałe? Język ma niebywałą moc kumulacji obrazomyśli w swoich zdaniowych wypowiedziach. Jednak, ich zrozumienie jest tylko i wyłącznie zrozumieniem własnych obrazów, które język wiąże w myśli. Trzeba zatem w sposób nieskończony zdać się na projekt nieustannego przekraczania siebie. Ale co to znaczy przekraczanie siebie? Jeżeli ma się na uwadze transcendencje własnej jaźni i usytuowanie jej ponad sytuacjami, w których się przebywa, to rzeczywiście przekraczanie jest wykraczaniem z siebie. Ale to nie koniec. Zrozumienie nie może opierać się na dualnej tożsamości podmiotu. Trzeba jeszcze dodatkowo wykazać się tutaj empatią. Jaźń musi wejść w relacje z czymś u kogoś, co pozwoli jej zintegrować się ze swoim rozmówcą, by go lepiej zrozumieć. A tym czymś jest - co zdziwi - wychowanie i kształcenie. Czy w ten sposób zbliżyliśmy się do próby ustanowienia postpedagogiki? Nie do końca. Na razie zbliżyliśmy się do obrazomyśli umieszczonego na początku tego tekstu motta.

$\mathrm{W}$ takim razie należy pójść $\mathrm{w}$ prowadzonych tutaj przemyśleniach dalej i w paru zdaniach streścić to, o czym będzie mowa w tym tekście. Ponieważ mamy tutaj do czynienia z koncepcją, której struktura ma charakter procesualny, to jej krótkie przybliżenie może być opisane „od dołu” lub „od góry”. Wybór jest znaczący, ponieważ opis oddolny pozwala nabudowywać elementy struktury na siebie i zwykle ten sposób uzasadniania swoich idei jest najczęściej stosowany przez myślicieli. Dla odmiany pójdziemy drogą odwrotną. Będzie to analiza, która musi uwzględniać swoją podbudowę i w takim razie jest czymś na pograniczu dedukcji i indukcji.

Punktem wyjścia (a głównie dojścia) jest podmiot. Nie etyczny, nie polityczny, nie religijny, czy inny, ale podmiot pedagogiczny. Wyłania się on ze sposobu, i to jest ważne, sposobu w jaki jaźń łączy się z czymś, co stanowi jej wychowanie. Skoro podmiot jest pedagogiczny, to musi to być jej przedmiot. W trakcie prowadzonych rozważań okazało się, że jaźń nie tylko łączy się z wychowaniem, ale również z kształceniem. Ale jak to się dzieje? Dzieje się to za sprawą edukacyjnego działania, do którego zwraca się podmiot, bowiem jest on zakładany przez to, co edukacyjne działania kreuje, czyli przez doświadczenie pedagogiczne. To, co dzieje się za sprawą edukacyjnego działania, wskazuje na edukacyjne działanie, które jest nośnikiem wychowania i kształcenia. Nośnik 
ten jest formatowany przez siłę motywacyjną wytwarzaną w doświadczeniu pedagogicznym. Siłą jest wychowanie, a motywacją kształcenie, co sprawia, że wychowanie przekłada się na tożsamość podmiotu, a motywacja na jego sprawczość. Co zatem generuje siłę motywacyjną edukacyjnego działania, które również formatuje potencjał myślenia w kształtowaniu własnej samoświadomości? Wskazaliśmy na pedagogiczne doświadczenie. Co je ustanawia? Muszą to być zasady myślenia i działania pedagogicznego - zasady, które pozwolą powiedzieć: Tak, to jest doświadczenie pedagogiczne, a nie estetyczne. Rzeczywiście, możemy tutaj przyjąć, że w pedagogice mamy cztery zasady myślenia i działania pedagogicznego. To one stanowią ostateczny filtr tego, co pojawia się w strukturze edukacyjnego działania jako siła motywacyjna. I jeśli zgodzimy się, że zasady te rzeczywiście istnieją, to ich ostateczna forma ma charakter indywidualny. Musi taki mieć, bo każdy podmiot w swojej samoświadomości jest niepowtarzalny. Co różnicuje zasady myślenia i działania tego doświadczenia? Doświadczenie jest zawsze doświadczeniem czegoś. W tym, oczywiście, przypadku będą to treści podpadające pod system informacyjny edukacji. I tu należy się zastanowić, czy rzeczywiście treści? Mówiąc o myśleniu i działaniu pedagogicznym, mamy na uwadze pewne oprzyrządowanie pedagogicznego doświadczenia - oprzyrządowanie, które ma przetwarzać treści i to w siłę motywacyjną. Jeżeli treści mają mieć wpływ na kształt doświadczenia pedagogicznego, muszą podlegać pedagogiczno-podmiotowej obróbce, bowiem w przeciwnym wypadku idea podmiotu pedagogicznego nie miałaby sensu, a jeżeli i nawet zgodzilibyśmy się na relację behawioralną pojawiających się treści w doświadczeniu pedagogicznym, wówczas podmiot pełniłby funkcję biernego obserwatora. Uaktywniając na ten moment wyobraźnię, wydaje się, iż zasady myślenia i działania pedagogicznego powinny podlegać indywidualizacji na podłożu swojej styczności z podmiotowością, której istnienie musi zakładać, i osobowością, do której zwrotnie muszą przystawać, gwarantując tym samym sens istnienia pedagogiki - sens, który ma kształtować ludzką osobowość. Nawiasem mówiąc, związek doświadczenia pedagogicznego z przekształcaną osobowością i odwrotnie, w swoim naukowym zapleczu, powinien kreować swoje podstawy i uzasadnienie, i to na podstawie założeń kognitywistyki.

\section{Próba ustanowienia postpedagogiki}

Nie potrzeba dużej wyobraźni, aby na podstawie powyższych, ogólnych informacji odnośnie tego, o czym będzie tutaj mowa, stwierdzić, że co wpisuje się w dorobek pedagogiki, stanowi podłoże dla - i to trzeba podkreślić - organicznego przekształcania się człowieka w istotę świadomą, myślącą i działającą na bazie - w tym przypadku - pedagogicznego kształtowania się ludzkiej podmiotowości. 
Nieszczęściem pedagogiki jest okupowanie jej przedmiotu, czy przedmiotów, przez różne dziedziny wiedzy naukowej. Ogranicza to jej dążenie do niezależności, a opisywana tożsamość ma swój zewnętrzny dyktat. Problemy pedagogiki dotyczą jej przedmiotu, metodologii, przynależności do nauki, sensowności i skuteczności oddziaływań w rzeczywistym świecie. A jeśli i to pominiemy, wówczas stajemy przed nadmiarem wytwarzanej w jej ramach informacji, które pedagogika ogólna próbuje na różne sposoby usystematyzować ${ }^{2}$ Głównie winę za ten stan rzeczy ponoszą uczeni, a w szczególności ci, którzy w swoim naukowym działaniu próbują zaznaczyć swoją obecność w rzeczywistości naukowej. To za ich sprawą nieustannie pojawiają się nowe definicje kluczowych dla tej dyscypliny pojęć, które w rzeczywistości nic nowego nie wnoszą. A co się tyczy systematyzacji, czy klasyfikacji, to na przykład sięgam do dwóch leżących obok mnie książek: Dzieje sześciu pojęć W. Tatarkiewicza $^{3}$ i Szaleństwo katalogowania U. Eco ${ }^{4}$. I co z nich wynika? Klasyfikowanie okazuje się niezbędną formą dla ludzkiego działania i kumulowania ludzkich wytworów w zbiory - formą, w której odzwierciedlają się ludzkie dzieje formą, która podlega przekształceniom - formą, której treści tylko dla nielicznych oznaczają miniony czas ludzkiej historii. Uczeni tworzą swój ślad we własnych dziejach, ale przyjdą kolejne nowe wydarzenia i tylko o nielicznych będzie się wspominać jako o znaku czasu w dziejach naszej cywilizacji.

Co w takim razie pozostawi po sobie pedagogika? Naukowo zmarginalizowana, może stanie się jedynie efemerydą, niejasnym wspomnieniem dla tych, którzy o rozwoju i przemianach ludzkiej osobowości będą wypowiadać się poprzez optykę technologii, polityki i ekonomii. Dlatego, dla nielicznych nauk o wychowaniu pozostanie nauczanie wychowujące i kształcące podporządkowane formom zinstytucjonalizowanym, kładących nacisk na zachowanie i utrzymanie się przy władzy. Dla pozostałych, w dobie prawdopodobnych klęsk żywiołowych, najważniejsze okaże się tylko przetrwanie. Wychowanie wówczas będzie podlegać żywiołom natury i z moralnego punktu widzenia będzie podlegać patologii.

Pedagogika jest jaka jest, a co z nią będzie to będzie. Z punktu widzenia postpedagogiki nie jest to dla niej obojętne, ponieważ bazuje ona na tym wszystkim, co wpisuje się w sens istnienia pedagogiki. Istotą postpedagogiki jest przejście z poziomu teorii i praktyki w sferę organiczną ludzkiego istnienia, która ukonstytuowana jest z elementów wpisujących się w przedmiotową problematykę pedagogiki. Oznacza to, że rezultaty badań pedagogiki stanowią o kondycji postpedagogiki, która wspiera się na nich, przetwarza je i konstytuuje swoją rzeczywistość. Istotą postpedagogiki jest, na ile to tylko możli-

\footnotetext{
${ }^{2}$ B. Śliwerski, Pedagogika ogólna. Podstawowe prawidłowości, Kraków 2012, s. 31-66.

${ }^{3}$ W. Tatarkiewicz, Dzieje sześciu pojęć, Warszawa 2012.

${ }^{4}$ U. Eco, Szaleństwo katalogowania, przekł. T. Kwiecień, Poznań 2009.
} 
we, odgraniczenie się od wpływów różnych dyscyplin wiedzy naukowej na jej sposób istnienia i funkcjonowania. Jej fundamenty mają opierać się na tym, co jest stricte pedagogiczne. $W$ takim razie, jedno z kluczowych haseł filozofii wzywające do powrotu do źródeł, staje się również aktualne dla postpedagogiki, przy czym w powrocie tym chodzi o zwrot ku treściom i ideom czysto pedagogicznym. Niemniej aktualna wiedza pedagogiczna, edukacyjna, wiedza o wychowaniu i kształceniu są bardzo ważne. Dąży się bowiem tutaj do przejścia od tego, co teoretycznie jest wytwarzane i praktycznie wdrażane do ich rzeczowego, podkreślmy rzeczowego, urzeczywistnienia w sferze bycia człowiekiem, którego docelową instancją jest rzeczowe kształtowanie osobowości warunkowanej sensem istnienia, przekształcania się i gotowości do działania podmiotu, który w tym przypadku jest określany jako podmiot pedagogiczny. Do tej idei powrócimy w ostatniej części niniejszego artykułu, ponieważ najpierw należałoby podać przykład, w czym partycypuje postpedagogika. Umożliwi to zrozumienie jej fenomenu, sensu istnienia i zadań, jakie sobie wyznacza. Poniższy przykład ma uświadomić motorykę tego przejścia, dla którego kluczowe jest poszukiwanie pytań koncentrujących się wokół tego „jak” pedagogika, edukacja, czy nauki o edukacji mogą stać się rzeczywistymi mechanizmami bycia istotą ludzką dzięki wytworom pedagogiki. Mniej ważne jest to, czym jest w swoich teoretycznych ustaleniach kształcenie, wychowanie, nauczanie, rozwój itd. i ich praktyczne implikacje. Mniej ważne, ale na tyle ważne, że te implikacje, jeżeli stają się częścią ludzkiej egzystencji, to nie mogą być zbagatelizowane, tym bardziej że treści te wpisują się w sens istnienia postpedagogiki. Ktoś mógłby się uprzeć, że takie koncepcje istnieją w pedagogice. Wystarczy sięgnać na przykład do klasyków - J.F. Herbarta, A.S. Neilla, J. Deweya czy R. Steinera. W postpedagogice jednak nie chodzi o jakieś podejście do człowieka i stosowanych formach nauczająco-wychowawczego oddziaływania na jego kształtowanie, ale o sam mechanizm tych przemian. Poniższy przykład stanowi pewną egzemplifikację takiego zamysłu. Nie jest to idea skończona, a tym samym dogłębnie przemyślana. Niektóre z pojawiających się tutaj treści będą zakładać przedwstępną wiedzę czytelnika na ich temat, kilka będzie miało charakter intuicyjny i będzie domagać się w przyszłości uzasadnień. Istotne jest to, aby zaprezentować zarys tego, czym ewentualnie miałaby zajmować się postpedagogika, a tym samym wskazać na siebie, pokazując czym jest.

\section{Jaźń źródłem istnienia podmiotu pedagogicznego}

Interesować nas będą zatem odpowiedzi na pytania: Jak należy rozumieć podmiot? Co jest źródłem podmiotu pedagogicznego? Jak powinno rozumieć się edukację i działanie w edukację w kontekście doświadczenia pedagogicznego? 
Udzielenie na powyższe pytania odpowiedzi będzie w pierwszym rzędzie domagać się odpowiedzi na pytanie: $W$ jaki sposób jaźń wchodzi w relacje z czymś, co określa jako swoje wychowanie? Pytanie to z uwagi na wychowanie jest pytaniem pedagogicznym. Gdybyśmy pytali o dobro, byłoby to pytanie etyczne. Gdybyśmy pytali o piękno, byłoby to pytanie estetyczne. Pytamy o wychowanie i dlatego próbę odpowiedzi na nie powinno skoncentrować się na problematyzacji tego, w czym jaźń jest ugruntowana. A ugruntowana jest $\mathrm{w}$ podmiocie $\mathrm{i}$ jego zaangażowaniu, po pierwsze, $\mathrm{w}$ to, $\mathrm{w}$ czym treści pedagogiki się konstytuują, czyli w pedagogiczne doświadczenie, a po drugie, $\mathrm{w}$ to, przez co praktycznie się wypowiada, czyli w edukacyjne działanie. Z powyższego można mniemać, że podmiot jest kreowany przez jaźń. Należy jednak dodać, że kreacja ta nie ma charakteru biernego ze strony podmiotu i nie jest też skoncentrowana tylko na działalności jaźni. Podmiot poprzez swoiste, edukacyjne odniesienie do pedagogicznego doświadczenia - o czym za chwilę - wymusza na jaźni wejście w relację z wychowaniem, a sposób kreacji tej relacji staje się źródłem wyłaniania się podmiotu. W takiej sytuacji można wstępnie sformułować następującą tezę: podmiot poprzez zaangażowanie w działanie edukacyjne pedagogicznego doświadczenia przymusza jaźń do wejścia w relacje z wychowaniem, a sposób kreacji tej relacji staje się źródłem formowania podmiotu wraz z jego tożsamością. Taki rodzaj podmiotu należy nazwać podmiotem pedagogicznym (zob. ryc. 1).

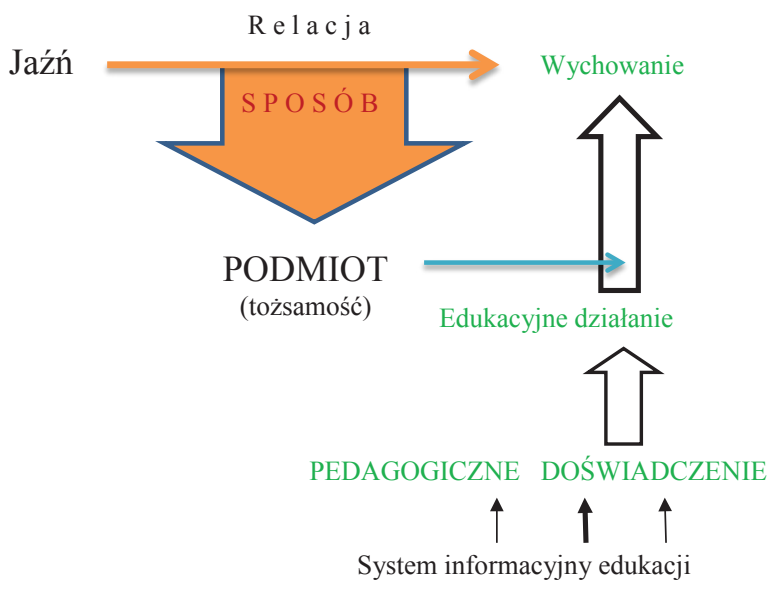

Ryc. 1. Podmiot pedagogiczny w relacji do doświadczenia pedagogicznego (Źródło: opracowanie własne)

W ramach krótkiego przypomnienia należy kilka zdań poświęcić podmiotowi i edukacji. Podmiot w języku łacińskim oznacza subiectum i sytuowany jest 
w opozycji do obiectum, czyli przedmiotu. Za tak zwany elementarz w tej dziedzinie wiedzy należy uznać książkę Ch. Taylora ${ }^{5}$ Źródła podmiotowości. Narodziny tożsamości nowoczesnej. Jak to bywa z wieloma pojęciami kluczowymi w nauce, gruntowne studium tego pojęcia przeprowadzone przez M. Kowalską ${ }^{6}$, czy A. Męczkowską ukazuje jego złożoność i trudności definicyjne. Podmiot w każdym razie, jak stwierdza J. Butler ${ }^{8}$, zwykle jest traktowany jako aktywna siła sprawcza, ale również możemy spotkać propozycje, w których podmiot zostaje sprowadzony do biernego przedmiotu. Na przykład, L. Althusser ${ }^{9}$ czy M. Foucault ${ }^{10}$ położyli w kilku swoich pracach nacisk na takie stosunki panowania, których zasadniczym celem jest sprowadzenie jednostek czy grup społecznych do podmiotów, którymi można zarządzać i je dyscyplinować. Niemniej jednak, należy podsumować i na co wskazuje M.S. Archer ${ }^{11}$, w ważnej dla rozwoju tej problematyki pracy: Człowieczeństwo. Problem sprawstwa, iż pojęcie podmiotu można sprowadzić do dwóch sposobów jego pojmowania. Po pierwsze, do samoświadomego podmiotu tożsamości (ang. self) i po drugie - do podmiotu działania (ang. agent). W niniejszej wypowiedzi rozumienie podmiotu będzie sprowadzone do wskazanych powyżej dwóch jego modusów rozumienia.

W tym miejscu należy jeszcze dodatkowo wyjaśnić sens rozumienia edukacji w ogóle i edukacyjnego działania w odniesieniu do doświadczenia pedagogicznego. Nawiązując przykładowo do ustaleń toruńskiego pedagoga R. Schulza, można przyjąć, iż „(..) pedagogika to składowa część systemu informacyjnego edukacji. To ogół procesów wzbogacania pedagogicznego doświadczenia, jego zapisu w określonych systemach symbolicznych (językach) $(. .)^{\prime \prime 12}$. Pedagogika jest zatem w tym wypadku nadbudową informacyjną dla zjawisk edukacyjnych. W związku z czym w sytuacji, w której doświadczenie pedagogiczne zobligowane jest wiedzą teoretyczną, to wówczas działanie edukacyjne w swojej pedagogii okazuje się działaniem zobligowanym siłą, której praktyczna sprawczość - w swoim kształtowaniu celów i zadan - motywuje do ich realizacji, wdrażania. W takiej sytuacji edukacja w ogóle będzie obejmować wszelkie zjawiska, które wpisują się w system informacyj-

${ }^{5}$ Ch. Taylor, Źródła podmiotowości. Narodziny tożsamości nowoczesnej, przekł. zbiorowy, Warszawa 2001.

${ }^{6}$ M. Kowalska, Dialektyka podmiotu, [w:] Podmiotowość i tożsamość, red. J. Migasiński, Warszawa 2001.

7 A. Męczkowska, Podmiot i pedagogika. Od oświeceniowej utopii ku pokrytycznej dekonstrukcji, Wrocław 2006.

${ }^{8}$ J. Butler, The Psychic Life of Power: Theories in Subjection, Stanford 1997.

${ }^{9}$ L. Althusser, Wodpowiedzi Johnowi Lewisowi, przekł. A. Staroń, Warszawa 1989.

${ }^{10}$ M. Foucault, Podmiot i władza, przekł. J. Zychowicz, Lewą Nogą, 1998, 10; tenże, Nadzorować i karać. Narodziny więzienia, przekł. T. Komendant, Warszawa 1998.

${ }_{11}$ M.S. Archer, Człowieczeństwo. Problem sprawstwa, przekł. A. Dziuban, Kraków 2013.

12 R. Schulz, Szkice z pedagogiki ogólnej, Torun 2015, s. 12. 
ny edukacji i w tym przypadku można mieć na uwadze treści wpisujące się na przykład $w$ tak zwany dekader edukacyjny w opracowaniu Z. Kwiecińskiego $^{13}$. Natomiast, edukacyjne działania to forma zawierająca w sobie siłę motywacyjną. Jej źródłem byłoby doświadczenie pedagogiczne, a miejscem docelowym możliwość wejścia w relację z jaźnią.

\section{Siła motywacyjna edukacyjnego działania}

Sens istnienia podmiotu pedagogicznego, świadcząc o pedagogicznym nacechowaniu ludzkiej egzystencji, wskazuje na pedagogiczne powiązania praktyki edukacyjnej z ludzką osobowością. Podmiot pedagogiczny bowiem, zwracając się poprzez edukacyjne działanie do doświadczenia pedagogicznego, odsłania strukturę zedukowanej osobowości, którą można uznać za egzystencjalny szablon, matrix pedagogiki. Tym samym, wskazany rodzaj doświadczenia pedagogicznego dostarcza działaniu edukacyjnemu pojęcie motywacyjnej siły, dzięki której jaźń skłonna jest wejść w relacje z pewną ideą wychowania. Oznacza to, że siła motywacyjna wynikająca z doświadczenia pedagogicznego wpisuje się $\mathrm{w}$ działanie edukacyjne i tym samym przysposabia jaźni do podjęcia aktywności, celem wejścia w relacje z jakąś ideą wychowania. Relacja, która przysposabia jaźń do aktywności, staje się sposobem formowania pedagogicznego podmiotu, w formowaniu którego zawiera się istota siły motywacyjnej zobligowanej jakąś ideą wychowania (zob. ryc. 2).

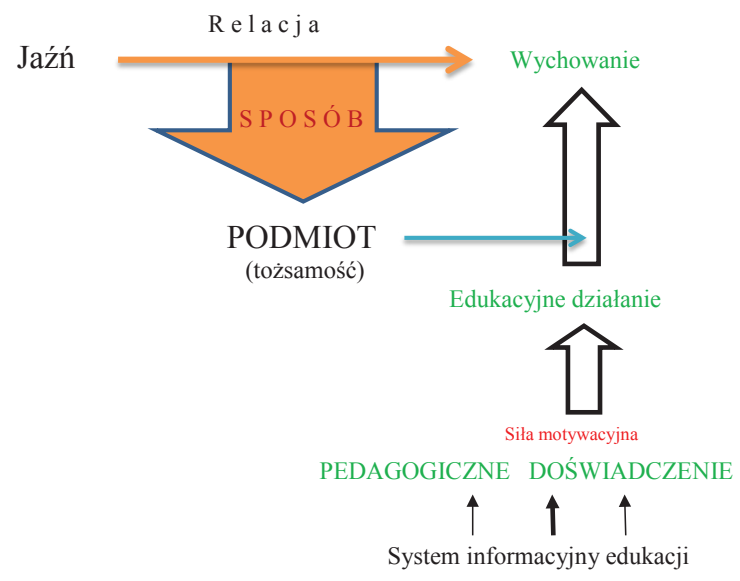

Ryc. 2. Podmiot pedagogiczny i siła motywacyjna (Źródło: opracowanie własne)

${ }^{13}$ Z. Kwieciński, Dziesięciościan edukacji (składniki i aspekty - potrzeba całościowego ujęcia), [w:] Wprowadzenie do pedagogiki. Wybór tekstów, red. T. Jaworska, R. Leppert, Kraków 1996, s. 31-41. 
W powyższych rozważaniach brakuje jeszcze wyjaśnienia, jak to się dzieje, że podmiot zwraca się do doświadczenia pedagogicznego. Wstępnie należy tutaj przyjąć, że istnienie doświadczenia pedagogicznego zakłada i poprzedza istnienie podmiotu pedagogicznego, do którego zwraca się poprzez działanie edukacyjne, które wyposażone jest w siłę motywacyjną. Siła ta uaktywnia działanie edukacyjne, której istotnym czynnikiem jest wychowanie. Pozwala nam to stwierdzić, że do działania edukacyjnego przylega podmiot, który zaangażowany jest w sens istnienia siły motywacyjnej, dzięki której przystaje do doświadczenia pedagogicznego i współuczestniczy w kształtowaniu siebie poprzez uaktywnianie się jaźni, która wchodzi w relacje z edukacyjnym wychowaniem. W takiej sytuacji możemy nieco zmodyfikować poprzednią tezę i stwierdzić, że zakładany przez pedagogiczne doświadczenie podmiot pedagogiczny przystaje do motywacyjnej siły doświadczenia pedagogicznego nadawanej edukacyjnemu działaniu, dzięki któremu podmiot aktywnie uczestniczy w kreowaniu się jaźni, której sposób wchodzenia w relację z czymś, co stanowi jej wychowanie, staje się podstawą istnienia podmiotu pedagogicznego.

\section{Zarys teorii doświadczenia pedagogicznego}

W dalszej kolejności prowadzonych tutaj rozważań należy mieć na uwadze dwa do rozwiązania zadania. W odniesieniu do pierwszego, należy naszkicować zarys teorii doświadczenia pedagogicznego, a w przypadku drugiego - wypracować model podmiotu pedagogicznego.

Zarys teorii doświadczenia pedagogicznego wymaga głębszych badań i pogłębionego namysłu. Niemniej jednak, dokonana już wstępnie problematyzacja doświadczenia pedagogicznego ukierunkowuje na dwa jej istotne aspekty. Po pierwsze, należy odnieść się do tego, co stanowi stricte zasady myślenia i działania pedagogicznego, a po drugie - do teorii wychowania, w których w zasadzie kładzie się nacisk na problematyzację drogi postępowania pedagogicznego. Pierwszy ten aspekt wskazuje, bez czego doświadczenie pedagogiczne w swoim myśleniu i działaniu nie może się obejść, a drugi z uwagi na to, z czym jaźń się łączy, czyli z wychowaniem - ukierunkowuje na jej teoretyczne ujęcie, które ma przystawać do zasad myślenia i działania pedagogicznego. To przystawanie do zasad, w swojej problematyzacji, odsłania dodatkowy element działania edukacyjnego. Jak później się okaże, obok wychowania pojawia się dodatkowy element o charakterze praktycznym, co pozwala nam wstępnie myśleć o nim jako o kształceniu. Jaźń w takim razie wchodzi w relacje nie tylko z wychowaniem, ale również z kształceniem. 
Kreując zatem teorię doświadczenia pedagogicznego, należy mieć na uwadze wykoncypowanie takiej struktury, której składowe będą wpisywać się $\mathrm{w}$ sens istnienia doświadczenia pedagogicznego. Pragnąc w takiej sytuacji zrealizować powyższy cel, to przede wszystkim należy zwrócić się do tego, co będzie świadczyć o istnieniu myślenia i działania pedagogicznego. I rzeczywiście, cztery tego typu zasady zostały wygenerowane z historii europejskiej cywilizacji przez znanego w Polsce filozofa i pedagoga pochodzącego z Berlina D. Bennera ${ }^{14}$. Dlaczego właśnie do tych zasad należy sięgnąć? Dlatego, ponieważ wskazują one na to, co swoiste dla pedagogiki, co nie jest warunkowane czynnikami społecznymi i genetycznymi, a więc w tym ich wskazaniu ujawnia się ich historyczny sens, wykraczający poza uzależnienie pedagogiki od różnych dziedzin wiedzy naukowej. Niemniej jednak, nie można zapominać, że treści doświadczenia pedagogicznego mają charakter przedteoretyczny lub teoretyczny.

Pomijając w tym miejscu, opracowane przez D. Bennera, założenia teoretyczne $\mathrm{w}$ jego koncepcji przekształcania się człowieka w istotę ludzką, na ten moment należy tylko zwrócić się do wskazanych przez myśliciela zasad, bowiem to one mają konstytuować formę doświadczenia pedagogicznego. Zasady te to ukształcalność, wezwanie do aktywności własnej, transformacja oddziaływań społecznych na pedagogiczne i niehierarchiczny oraz ateleologiczny układ różnych rodzajów praxis, czyli działań w ramach zindywidualizowanej humanitas. Istotne $\mathrm{w}$ jego ustaleniach jest to, że pierwsze dwie zasady mają wymiar konstytutywny, aprioryczny i indywidualny, a dwie kolejne - regulatywny, aposterioryczny, doświadczalny i społeczny. Wydawać by się mogło, iż mając na uwadze sens istnienia i kreacji podmiotu, należałoby skoncentrować prowadzone tutaj rozważania na zasadach konstytutywnych, ponieważ są aprioryczne i właśnie na ich podstawie powinno się stworzyć projekt struktury doświadczenia pedagogicznego. Jednak D. Benner wyraźnie podkreśla, że obie grupy zasad wzajemnie się dopełniają. Ponadto, sens tych zasad odnosi się do myślenia i działania pedagogicznego, do teorii i praktyki, i nie jest powiedziane, która zasada jest teoretyczna, a która praktyczna. Fundamentalne dla koncepcji doświadczenia pedagogicznego i pedagogicznego podmiotu jest to, że zasady te, o czym była mowa powyżej, nadają działaniu edukacyjnemu siłę motywacyjną, dzięki której jaźń wchodzi w relacje z czymś, co określa jako swoje wychowanie, a tym czymś co formatuje wychowanie w obszarze działania edukacyjnego są zasady. Co więcej, doświadczenie pedagogiczne okazuje się miejscem integracji pedagogicznej teorii z praktyką - miejscem, w którym rozum łączy się z intelektem, a także

14 D. Benner, Pedagogika ogólna: Wprowadzenie do myślenia i działania pedagogicznego w ujęciu systemowym i historyczno-problemowym, przekł. D. Stępkowski, Warszawa 2015. 
miejscem, w którym teoria znajduje swoje uzasadnienie w praktyce. Miejsce to jest w konsekwencji spotkaniem co najmniej dwóch podmiotów pedagogicznych, z których jeden w sensie dydaktycznym wzywa drugiego do aktywności własnej, aby dokonało się w nim ukształcanie (uaktywnienie zasad konstytutywnych).

Możemy zatem zaproponować następującą strukturę doświadczenia pedagogicznego (zob. ryc. 3). Składać się ona będzie, z jednej strony, z zasad konstytutywnych, natomiast z drugiej - z zasad regulatywnych.

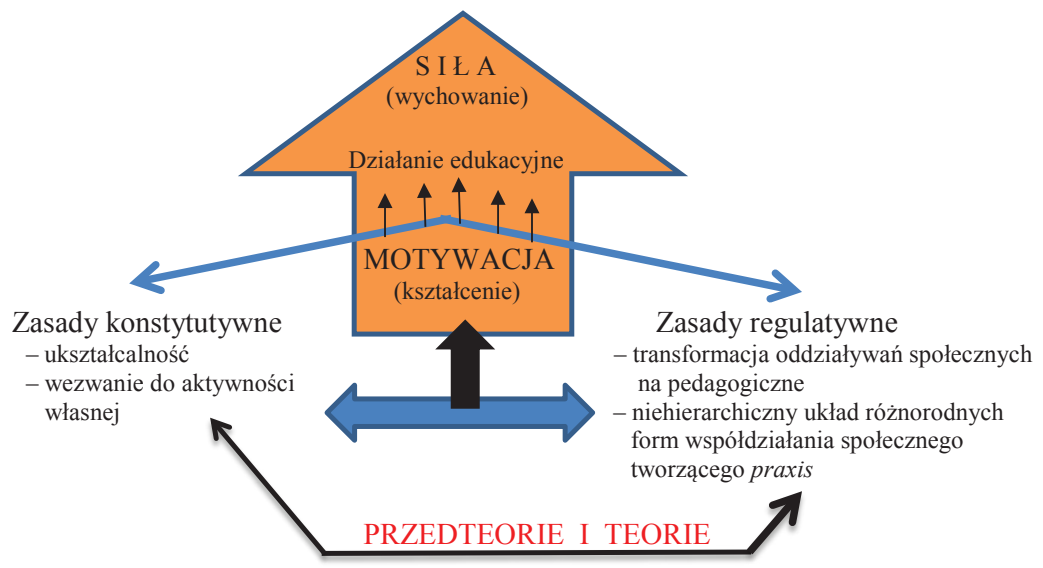

Ryc. 3. Struktura doświadczenia pedagogicznego z siłą motywacyjną tworzącą edukacyjne działanie

(Źródło: opracowanie własne)

Zasady konstytutywne należy sprowadzić do działań, które w swoim formowaniu, ustanawianiu mają charakter zabiegający, żądający, egzekwujący, wywierający. Z kolei, zasady regulatywne świadczą o porządkowaniu, ustanawianiu, które domagają się przyzwolenia, aprobaty, czy troski, jak to przykładowo widział M. Heidegger ${ }^{15}$. Obie grupy zasad w zależności od treści doświadczenia edukacyjnego stają się źródłem siły motywacyjnej działania edukacyjnego.

Doświadczenie pedagogiczne, jak to już zostało zasugerowane w swojej istocie, nie obejmuje doświadczenia, które w sposób bierny odtwarza treści systemu informacyjnego edukacji. Treści te, z uwagi na zasady myślenia i działania pedagogicznego, podlegają w nich przekształceniom. Przy czym, ustrukturyzowanie tych treści w działanie edukacyjne stanowi siłę motywa-

${ }^{15}$ M. Heidegger, Bycie i czas, przekł. B. Baran, Warszawa 1994. 
cyjną dla jaźni, do której przystaje podmiot, na sposób, w jaki jaźń łączy się z wychowaniem. Sposób ten ukazuje tożsamość i sprawczy charakter podmiotu, co przekłada się na aktywne jego uczestniczenie w działaniu edukacyjnym, będąc przy tym, uwikłanym w jego stanowienie, treściowe urzeczywistnianie. Oznacza to, że doświadczenie pedagogiczne w swoim działaniu edukacyjnym jest źródłem dla działającego podmiotu - źródłem jego tożsamości i sprawczej aktywności, wynikającej z siły motywacyjnej działania edukacyjnego.

Pomimo że zasady wpisane $\mathrm{w}$ doświadczenie pedagogiczne wzajemnie się dopełniają, można zastanowić się, której grupie zasad należałoby przyznać pierwszeństwo w kwestiach inicjowania działania edukacyjnego i stanowienia podmiotu. Czy mają to być zasady, które konstytuują czy te, które regulują? W moim przekonaniu, z uwagi na indywidualny status podmiotu, początek doświadczenia pedagogicznego należy usytuować w doświadczaniu treści związanych z zasadami konstytutywnymi, czyli z ukształcalnością i wezwaniem do aktywności własnej. Doświadczanie tych treści zobligowane jest egzekwowaniem, żądaniem, które domaga się przyzwolenia, aprobaty, a więc i uporządkowania, ustanowienia wynikających z zasad regulatywnych. Mamy w konsekwencji, w przypadku doświadczenia pedagogicznego do czynienia z czymś, co można określić jako konstytutywna regulatywność. To w jej ramach można stwierdzić, że najpierw musi być żądanie czegoś, aby coś $\mathrm{w}$ dalszej fazie działania mogło podlegać przyzwoleniu. Aprobata ta wpisana w zasady regulatywne staje się zatem warunkiem dopełnienia (działania) i zrozumienia (myślenia) wychowania. Dlatego to co konstytuowane, musi być zregulatywowane.

\section{Model podmiotu pedagogicznego}

W ten oto sposób wyłania się sytuacja, w której doświadczenie pedagogiczne ufundowane na tym, co samo w sobie regulatywnie konstytuuje i wpisuje się w naturę samej jaźni, pozwala teraz przejść do rozważań na temat modelu podmiotu pedagogicznego (zob. ryc. 4).

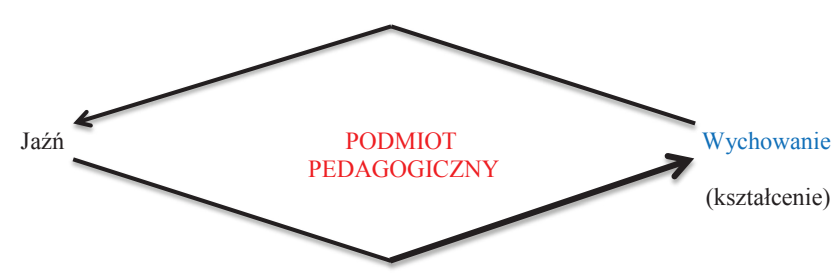

Ryc. 4. Podmiotowość pedagogiczna

(Źródło: opracowanie własne) 
Twierdząc w tym momencie, że jaźń kreuje siebie, odnosząc się do tego, co określa jako swoje wychowanie, to wychowanie może być warunkowane koncepcjami intencjonalnymi lub funkcjonalnymi, na co wskazuje np. D. Benner ${ }^{16}$ lub patrząc szerzej - teorie wychowania można przyporządkować do podejść postmodernistycznych, funkcjonalistycznych, interakcjonistycznych i radykalnych, jak to na przykład czyni B. Śliwerski ${ }^{17}$, nawiązując formalnie do sporządzonej przez R.G. Paulstona i M. Liebmana ${ }^{18}$ mapy społeczności dyskursywnych.

I tak, w relacji jaźń - wychowanie, do której przystaje jako jej podłoże edukacyjne działanie, sposób kreacji tej relacji, oparty przykładowo na teoriach wychowania zobligowanych intencjonalnie, ma charakter przyczynowo-skutkowy, dążąc tutaj do zespolenia w jedno intencję i rezultat. Z kolei, odnosząc się do teorii wychowania skoordynowanych na przykład funkcjonalnie, relacja ta ma na celu zidentyfikowanie funkcji jej wychowawczych elementów $\mathrm{w}$ całym procesie edukacji, który w tym przypadku wynika z doświadczenia pedagogicznego znormalizowanego dyrektywami - idąc na przykład tropem J. Kmity ${ }^{19}$. Obie przywołane tutaj grupy teorii wychowania stanowią teoretyczne zaplecze dla zaistnienia konkretnych form edukacyjnego działania, które najpierw jako zbiory informacji podpadające pod przedteoretyczną lub teoretyczną systematyzację, podlegają zasadom myślenia i działania pedagogicznego, które je następnie przetwarzają i kondensują w siłę motywacyjną edukacyjnego działania. Przy czym, i to jest najważniejsze, sposób kreacji podmiotu oparty na sile teorii wychowania wskazuje na sposoby problematyzacji doświadczenia pedagogicznego koncentrujące się na postępowaniu pedagogicznym w edukacyjnym działaniu. Na ten fakt zwraca uwagę D. Benner ${ }^{20} \mathrm{~W}$ nieco innym kontekście swoich rozważań. Edukacyjne działanie jako nośnik informacji usystematyzowanych przez zasady myślenia i działania pedagogicznego, jeżeli będzie oparte tylko i wyłącznie na teoriach wychowania, będzie tylko źródłem tożsamości podmiotu. To bycie jakimś jest już formą istnienia, które wynika z rozstrzygnięcia kwestii legitymizacji przymusu zawartych w teoriach wychowania. Na ten aspekt w wychowaniu zwrócił już uwagę I. Kant, pytając: „Jak możliwa jest wolność przy przymusie” ${ }^{21}$. Formy sprawowania władzy wpisujące się w system informacyjny edukacji doświadczenia pedagogicznego jednostek odzwierciedlają się w zasadach, któ-

16 D. Benner, Pedagogika ogólna, s. 147-169.

17 B. Śliwerski, Pedagogika ogólna, s. 46-47.

18 R.G. Paulston, M. Liebman, APS conceptual mapping project, Rechearch Raport, 1993, 2, s. 9.

19 J. Kmita, Konieczne serio ironisty. O przekształcaniu się problemów filozoficznych w kulturoznawcze, Poznań 2007; G. Banaszak, J. Kmita, Społeczno-regulacyjna koncepcja kultury, Warszawa 1994.

20 D. Benner, Pedagogika ogólna, s. 169.

21 I. Kant, O pedagogice, przekł. S. Sztobryn, Łódź 1999, s. 53. 
rych działania edukacyjne naznaczają jaźń siłą doświadczanej władzy, która w swoim sprawowaniu staje się tożsamościowym podłożem wyłaniającego się podmiotu. Oznacza to dodatkowo, że sens bycia podmiotem nie może opierać się tylko na jego tożsamości i zawierać się w formule „ja jestem”. Sens jego istnienia wiąże się dodatkowo z jego aktywnością, motywacją ukierunkowaną na cele i zadania. Taki punkt widzenia pozwala $w$ rezultacie dostrzegać w działaniu edukacyjnym nie tylko siłę wychowawczą, ale również moc sprawczą, której motywacja zawiera się w kształceniu (zob. ryc. 5). Prowadzi to zatem do stanowiska, że o ostatecznej formie działania edukacyjnego decydują usystematyzowane $\mathrm{w}$ doświadczeniu pedagogicznym idee wychowania i kształcenia. Ich przedteoretyczność czy teoretyczność pozwala podmiotowi pedagogicznemu nie tylko doświadczać siebie w obliczu własnej jaźni, ale również w sposób sprawczy wpływać na rzeczywistość. To świadome działanie $\mathrm{w}$ świecie rzeczywistym zwrotnie przekłada się na modelowanie informacji edukacyjnych w obszarze doświadczenia pedagogicznego. Można przyjąć za Z. Kwiecińskim²2, że informacje te są skumulowane w tak zwanym dekaedrze edukacyjnym. Ich teoretyczna struktura normalizuje procesy edukacyjne poprzez ich nadmiar lub niedomiar pojawiający się w doświadczeniu pedagogicznym, aby następnie podlegać zasadom myślenia i działania pedagogicznego.

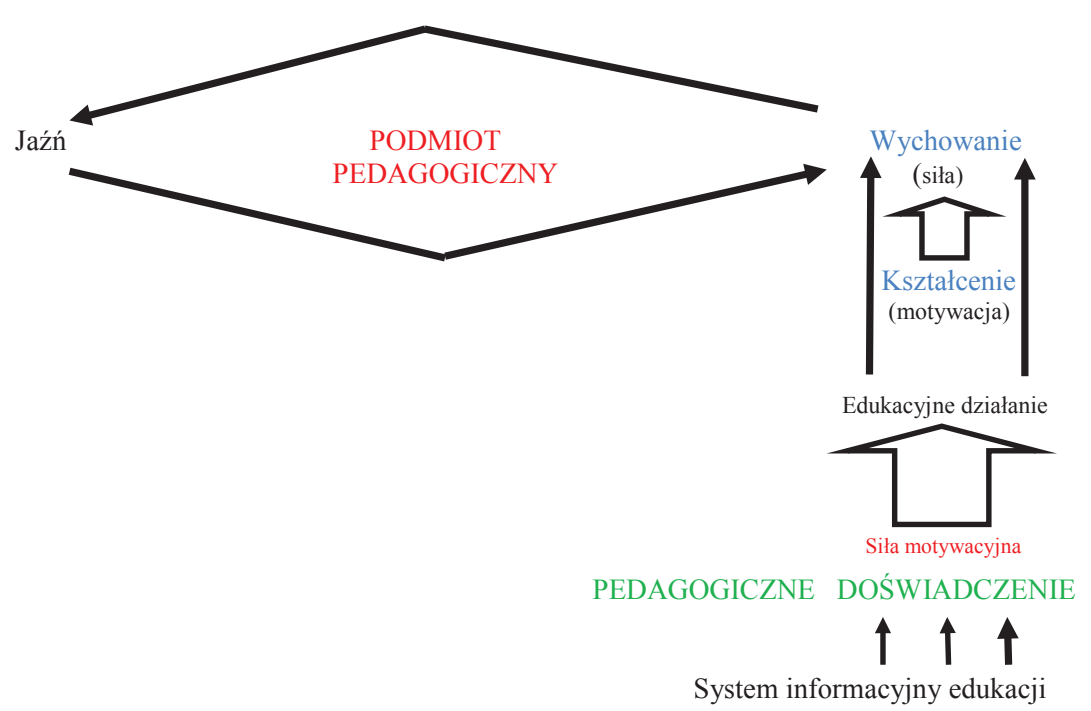

Ryc. 5. Podmiot pedagogiczny i siła motywacyjna pedagogicznego doświadczenia (Źródło: opracowanie własne)

${ }^{22}$ Kwieciński Z., Dziesięciościan edukacji. 
Podsumowując, należy stwierdzić, iż próba opracowania podmiotu pedagogicznego pozwala doszukiwać się w jego kreacji swoistego dla pedagogiki myślenia i działania pedagogicznego. Swoistość ta obdarza myślącą jaźń siłą sprawczą wynikającą z wpływów wychowania i kształcenia na jednostkowe doświadczenia stanowiące doświadczenie pedagogiczne. Treści tego doświadczenia przejawiają się w edukacyjnym działaniu, do którego przystaje podmiot, mogąc poprzez jaźń odnieść się do siebie, do doświadczanych informacji edukacyjnych i konkretnie działać w świecie rzeczywistym. Co zaś się tyczy zasad myślenia i działania pedagogicznego, to $w$ prowadzonych tutaj rozważaniach należy je traktować nie tylko jako narzędzie przekształcające procesy edukacyjne $\mathrm{z}$ ich oblicza teoretycznego $\mathrm{w}$ praktyczne, ale też jako formę wpisującą się w struktury ludzkiej osobowości. Założenie to ma służyć idei przemiany i rozwoju, ponieważ zmiany zachodzące w zasadach przekładają się na zmiany dokonujące się w osobowości i odwrotnie - zmiany osobowe kształtują zasady.

\section{Postpedagogika - rozważania podsumowujące}

Czy nazwa postpedagogika $\mathrm{w}$ pełni odpowiada zawartym $\mathrm{w}$ tym rozważaniu intencjom? Mamy tutaj do czynienia z wykorzystaniem treści pedagogiki celem wypracowania doświadczenia pedagogicznego i dookreślenia podmiotu pedagogicznego. Nie jest to zatem spojrzenie "meta”, odnoszące się z wyższej płaszczyzny poznania do tego co pedagogiczne, ani też kreowanie filozoficznej struktury pedagogiki ogólnej dla jej teoretycznego, poznawczego odniesienia się do treści samej pedagogiki. Ponadto, pojęcie metapedagogika - bo o nim tutaj mowa - ma już w pedagogice ogólnej swoją treściową i zadaniową przynależność. Można też było pomyśleć o nazwie Nowa Pedagogika, a więc o czymś na wzór Nowej Fenomenologii w propozycji H. Schmitza ${ }^{23}$. W książce tej autor odchodzi od klasycznego podejścia do fenomenologii, koncentrując się bardziej na filozofii bycia. Ważne jest to i być może nazwa Nowa Pedagogika byłaby zasadna, jeśli uwzględniłoby się fakt, iż H. Schmitz w swojej pracy kładzie nacisk na sens istnienia podmiotu, na to - jakie warunki muszą być spełnione, aby w określony sposób dokonało się jego ukształtowanie. W tym kontekście zasadna byłaby nazwa pedagogika podmiot. Ostatecznie autor opowiada się za nazwą postpedagogika. Czy jest to nazwa adekwatna do prowadzonych tutaj przemyśleń? „Post” w sumie oznacza to, co jest "po", a w sensie naukowym odnosi się zwykle do tego, co wcześniej było pominięte lub bezrefleksyjnie wykorzystane. Trzymając 2015.

${ }^{23}$ H. Schmitz, Nowa Fenomenologia. Krótkie wprowadzenie, przekł. A. Przełębski, Warszawa 
się zatem tej drugiej wykładni, to postpedagogika oznacza wykorzystanie wiedzy pedagogicznej, sprowadzonej do nauk o wychowaniu i kształceniu, i odniesienie jej kluczowych pojęć do narzędzi o organicznej denotacji ${ }^{24}$. Sens, a przede wszystkim możliwość ucieleśnienia treści pedagogiki wynika tutaj z zasady ukształcalności (zasada konstytutywna doświadczenia pedagogicznego), do której między innymi przystaje w swojej egzystencji cielesność. To ona poszukuje organicznej formy dla swojej wypowiedzi, która ostatecznie przystaje do podmiotu i do osobowości.

Zatem, zadaniem postpedagogiki powinno być przede wszystkim dookreślenie struktury doświadczenia pedagogicznego, dalej opracowanie modelu pedagogicznego podmiotu oraz ustalenie rzeczywistego związku między kreacją ludzkiej podmiotowości a zmianami, jakie dokonują się w osobowości. Niewątpliwie, mając na uwadze działanie edukacyjne, które wyposaża jaźń w określone treści teoretyczne i praktyczne, należałoby skoncentrować uwagę na sposobie wyłaniania się z tego wyposażania podmiotowości. Sposób ten - i tutaj należy przeprowadzić dodatkowe badania - prawdopodobnie powinien opierać się na prawidłowościach prakseologiczno-metodycznych. Możliwe, że w sposób kreacji podmiotu pedagogicznego wpisują się dyrektywy wypracowane przez siłę motywacyjną działania edukacyjnego. Powinny one zatem zawierać w sobie określone normy nauczania wychowującego i kształcącego. Ich treści, zawierające określone znaczenia, powinny okazać się tutaj podstawą dla tożsamości pedagogiki i formą-wzorcem do działań o charakterze sprawczym.

Niewątpliwie, aby nie popaść $\mathrm{w}$ tym projekcie $\mathrm{w}$ strukturę czysto organiczną i w coś na wzór, co podpada pod behawioryzm, to sens istnienia podmiotu i ludzkiej osobowości musi podlegać ideom humanistyki. W tym kontekście warto pomyśleć o edukacyjnym działaniu zawierającym siłę motywacyjną jako o przedsięwzięciu, w którym wychowanie byłoby wy-chowaniem, tak jak ten zwrot pojmuje A.E. Szołtysek ${ }^{25}$, gdzie wy-chowanie jest wydobywaniem na jaw tego, co ukryte - co w swoim uczłowieczaniu pozwala każdej jednostce z osobna wydobyć i wdrożyć w podmiot prawdę (aletheia) swojej egzystencji.

Być może, dzięki postpedagogice wprowadzi się w obszar pedagogiki nową wiedzę na temat podmiotu i inaczej zacznie postrzegać dorobek naukowo-filozoficzny nauk o wychowaniu. Istotne jednak jest to, że w swojej formalnej niezależności, $\mathrm{w}$ jakimś zakresie idea istnienia pedagogiki wyzwala się spod wpływów różnych dziedzin wiedzy naukowej, które przywłaszczają sobie jej podstawy statusowe lub narzucają własną wizję rozumienia wy-

24 Muszę wspomnieć, iż w pracy Pedagogiczne tworzenie istoty ludzkiej podmiot usytuowałem poza ludzkim ciałem, ale w wymienionej pracy przyjąłem inną optykę rozważań.

25 A.E. Szołtysek, Filozofia edukacji. Kształtowanie umystu, Kraków 2013, s. 120-121. 
chowania czy kształcenia. I jeśli się okaże, że postpedagogika ma swoją rację bytu, wówczas zasadne będzie mówienie o pedagogice itp. nie jako o nauce społecznej, ale o nauce stricte pedagogicznej.

\section{BIBLIOGRAFIA}

Althusser L., W odpowiedzi Johnowi Lewisowi, przekł. A. Staroń, Studencka Oficyna Almapress, Warszawa 1989.

Archer M.S., Człowieczeństwo. Problem sprawstwa, przekł. A. Dziuban, Zakład Wydawniczy Nomos, Kraków 2013.

Banaszak G., Kmita J., Spoteczno-regulacyjna koncepcja kultury, Instytut Kultury, Warszawa 1994.

Benner D., Pedagogika ogólna: Wprowadzenie do myślenia i działania pedagogicznego w ujęciu systemowym i historyczno-problemowym, przekł. D. Stępkowski, Wydawnictwo Uniwersytetu Kardynała Stefana Wyszyńskiego, Warszawa 2015.

Butler J., The Psychic Life of Power: Theories in Subjection, Stanford University Press, Stanford 1997.

Eco U., Szaleństwo katalogowania, przekł. T. Kwiecień, Dom Wydawniczy REBIS, Poznań 2009.

Foucault M., Nadzorować i karać. Narodziny więzienia, przekł. T. Komendant, Wydawnictwo Aletheia, Warszawa 1998.

Foucault M., Podmiot i władza, przekł. J. Zychowicz, Lewą Nogą, 1998, 10.

Heidegger M., Bycie i czas, przekł. B. Baran, Państwowe Wydawnictwo Naukowe, Warszawa 1994.

Kant I., O pedagogice, przekł. S. Sztobryn, Wydawnictwo Dajas, Łódź 1999.

Kmita J., Konieczne serio ironisty. O przekształcaniu się problemów filozoficznych w kulturoznawcze, Wydawnictwo Naukowe UAM, Poznań 2007.

Kowalska M., Dialektyka podmiotu, [w:] Podmiotowość i tożsamość, red. J. Migasiński, Wydawnictwo Wydziału Filozofii i Socjologii UW, Warszawa 2001.

Kwieciński Z., Dziesięciościan edukacji (składniki i aspekty - potrzeba całościowego ujęcia), [w:] Wprowadzenie do pedagogiki. Wybór tekstów, red. T. Jaworska, R. Leppert, Oficyna Wydawnicza Impuls, Kraków 1996.

Męczkowska A., Podmiot i pedagogika. Od oświeceniowej utopii ku pokrytycznej dekonstrukcji, Wydawnictwo Dolnośląskiej Szkoły Wyższej Edukacji TWP, Wrocław 2006.

Paulston R.G., Liebman M., APS conceptual mapping project, Rechearch Raport, 1993, 2.

Schmitz H., Nowa Fenomenologia. Krótkie wprowadzenie, przekł. A. Przełębski, Wydawnictwo Aletheia, Warszawa 2015.

Schulz R., Szkice z pedagogiki ogólnej, Wydawnictwo Adam Marszałek, Torun 2015.

Szołtysek A.E., Filozofia edukacji. Kształtowanie umystu, Oficyna Wydawnicza Impuls, Kraków 2013.

Śliwerski B., Pedagogika ogólna. Podstawowe prawidłowości, wyd. 2 popr., Oficyna Wydawnicza Impuls, Kraków 2012.

Tatarkiewicz W., Dzieje sześciu pojęć, Wydawnictwo Naukowe PWN, Warszawa 2012.

Taylor Ch., Źródła podmiotowości. Narodziny tożsamości nowoczesnej, przekł. zbiorowy, Wydawnictwo Naukowe PWN, Warszawa 2001. 